\title{
Peningkatan Kompetensi Siswa SMA di Kabupaten Sumba Timur dalam Menghadapi Kompetisi Sains Nasional Tingkat Provinsi
}

\author{
Erwin Randjawali*1, Mayun Erawati Nggaba², Anggriati Ledu Ngaba3 ${ }^{3}$ Yuliana \\ Tamu Ina Nuhamara ${ }^{4}$, Elsy S. H. Taunu ${ }^{5}$, Darius Imanuel Wadu', Stevvileny Angu \\ Bima $^{7}$, Iona Lisa Ndakularak ${ }^{8}$, Yuliana S. Eko9 , Irna Natalis Sanit ${ }^{10}$, Itha Priyastiti11, \\ Mega Retno Wulandari ${ }^{12}$
}

\author{
1,2,3,4,5,6,7,8,9,10,11,12Program Studi Pendidikan Matematika, Fakultas Keguruan dan Ilmu Pendidikan, \\ Universitas Kristen Wira Wacana Sumba, Indonesia \\ *e-mail: erwinrandjawali@unkriswina.ac.id ${ }^{1}$ mayun@unkriswina.ac.id ${ }^{2}{ }_{2}$ \\ anggriatiledungaba@unkriswina.ac.id ${ }^{3}$ yulinuhamara@unkriswina.ac.id ${ }^{4}{ }_{2}$ elsysenides@unkriswina.ac.id ${ }^{5}$.

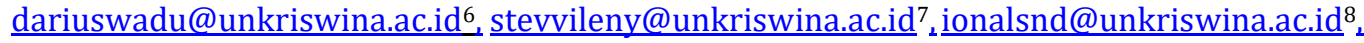

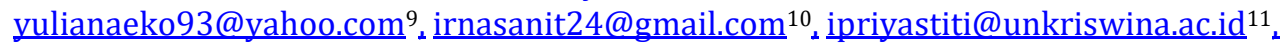 \\ mega@unkriswina.ac.id ${ }^{12}$
}

\begin{abstract}
Abstrak
Salah satu bentuk pelaksanaan kegiatan Pengabdian kepada Masyarakat yang dilaksanakan oleh dosen Prodi Pendidikan Matematika Universitas Kristen Wira Wacana Sumba adalah memberikan pendampingan bagi siswa calon peserta KSN-P. Dengan adanya pandemi COVID-19 sehingga mempengaruhi tingkat pemahaman siswa terkait materi Fisika. Oleh karena itu diperlukan kegiatan pendampingan sehingga dapat meningkatkan pemahaman siswa calon peserta KSN-P. Kegiatan pengabdian ini bertujuan untuk memberikan edukasi kepada siswa melalui proses pendampingan, sehingga dapat terjadi peningkatan kompetensi yang dibutuhkan untuk menyelesaikan soal-soal KSN-P. Metode pelaksanaan kegiatan PkM ini adalah dengan memberikan pendampingan menggunakan metode ceramah dan pengerjaan latihan-latihan soal dengan durasi waktu yang dibatasi untuk membiasakan siswa dengan soal-soal KSN-P. Hasil dari pelaksanaan PkM ini menunjukkan bahwa telah terjadi peningkatan kompetensi pada siswa calon peserta KSN-P, baik pada konsep-konsep Fisika maupun pada keterampilan untuk menggunakan persamaanpersamaan Matematika yang dibutuhkan dalam penyelesaian soal. Dengan demikian dapat disimpulkan bahwa kegiatan PkM ini telah mencapai tujuan yang direncanakan.
\end{abstract}

Kata kunci: Fisika, KSN-P, Pendampingan, Pengabdian

\section{Abstract}

One kind of the Community Service activities carried out by lecturers of the Mathematics Education Study Program at the Universitas Kristen Wira Wacana Sumba is to provide assistance to prospective students who are KSN-P participants. The presence of the COVID-19 pandemic affects the level of students' understanding of Physics material. Therefore, mentoring activities are needed so that they can increase the understanding of prospective KSN-P students. This service activity aims to provide education to students through the mentoring process, so that there can be an increase in the competencies needed to solve KSN-P questions. The method of implementing this PkM activity is to provide assistance using the lecture method and working on practice questions with a limited time duration to familiarize students with KSN-P questions. The results of the PkM implementation indicate that there has been an increase in the competence of prospective students participating in KSN-P, both in physics concepts and skills in using mathematical equations needed in solving problems. Thus it can be concluded that this PkM activity has achieved the planned objectives.

Keywords: KSN-P, Mentoring, Physics, Service

\section{PENDAHULUAN}

Kegiatan Pengabdian kepada Masyarakat (PkM) merupakan salah satu di mana sivitas akademika di perguruan tinggi menggunakan ilmu pengetahuan maupun teknologi untuk meningkatkan kesejahteraan masyarakat serta mencerdaskan bangsa (Standar Nasional Pendidikan Tinggi Nomor 3, 2020). Melalui kegiatan ini, para dosen beserta mahasiswa 
mentransformasikan ilmu pengetahuannya kepada masyarakat, sehingga dapat diadaptasi dan dikembangkan untuk meningkatkan kualitas hidup.

Salah satu bentuk kegiatan yang dilakukan oleh Program Studi Pendidikan Matematika sebagai upaya untuk mencerdaskan anak bangsa adalah dengan memberikan pendampingan bagi siswa SMA Negeri 2 Waingapu di Kabupaten Sumba Timur. Kegiatan pendampingan tersebut bertujuan untuk mempersiapkan siswa dalam mengikuti kegiatan Kompetensi Sains Nasional Tingkat Provinsi (KSN-P) Tahun 2021. Dengan persiapan yang matang, maka siswa tersebut dapat mengikuti KSN-P dengan baik.

KSN-P merupakan kegiatan rutin yang diselenggarakan oleh Pusat Prestasi Nasional Kemdikbudristek yang bertujuan untuk meningkatkan semangat juang siswa, serta sebagai wadah bagi pengembangan bakat dan minat siswa sehingga dapat memiliki prestasi di bidang sains. Terdapat 9 (sembilan) bidang keilmuan yang dikompetisikan pada KSN ini, salah satunya adalah bidang Fisika. Agar dapat mengikuti KSN-P, maka siswa harus dinyatakan lulus seleksi Kompetisi Sains Nasional Tingkat Kabupaten (KSN-K). Selain itu, pelaksanaan KSN-P di 2021 dilakukan secara daring (online) dikarenakan merebaknya wabah COVID-19 (Ibrahim et al., 2021).

Pandemi COVID-19 turut membawa dampak di bidang pendidikan. Hal ini mengakibatkan interaksi secara langsung antara guru dan siswa menjadi terbatas, serta mempengaruhi minat belajar siswa (Hairiah, 2021). Padahal materi yang diujikan pada kegiatan KSN-P Fisika Tahun 2021 tidak terlepas dari materi-materi pembelajaran yang telah diajarkan di sekolah. Dengan adanya pandemi COVID-19 mengakibatkan penyesuaian bentuk pembelajaran yang digunakan di sekolah-sekolah. Beberapa sekolah melaksanakan pembelajaran secara daring (online). Akan tetapi, menurut hasil penelitian diperoleh informasi bahwa pembelajaran Fisika secara daring pada masa pandemi COVID-19 menjadi tidak efektif (Talu et al., 2021). Hal ini turut berdampak pada tidak optimalnya penyerapan materi pembelajaran. Salah satu penyebabnya adalah terbatasnya media dalam pembelajaran maupun durasi waktu pelaksanaan pembelajaran (Bhagaskara et al., 2021). Oleh karena itu, diperlukan kegiatan tambahan selain pembelajaran di kelas online, sehingga dapat meningkatkan kompetensi yang dibutuhkan siswa pada saat mengikuti KSN-P. Salah satu bentuk kegiatan tambahan yang dapat dilakukan adalah dengan memberikan pendampingan. Pendampingan dapat meningkatkan

Berdasarkan hasil wawancara dengan guru pendamping KSN-P di SMA Negeri 2 Waingapu diperoleh informasi bahwa siswa dampingan masih belum dapat menguasai konsepkonsep dasar Fisika, serta belum terampil menggunakan persamaan-persamaan Matematika dalam menyelesaikan soal. Hal ini juga didukung oleh hasil test awal yang diberikan kepada siswa calon peserta KSN-P. Dari tes awal tersebut diperoleh informasi bahwa siswa belum memahami konsep-konsep Fisika yang menjadi dasar untuk mengerjakan soal KSN-P. Mengacu pada temuan di lapangan tersebut, maka tujuan pelaksanaan kegiatan Pengabdian kepada Masyarakat yang dilakukan oleh Prodi Pendidikan Matematika Unkriswina Sumba adalah untuk memberikan edukasi terkait kompetensi-kompetensi yang diperlukan oleh siswa dalam mengikuti kegiatan KSN-P. Dengan demikian, pelaksanaan kegiatan pendampingan oleh dosen Unkriswina Sumba secara intensif diharapkan dapat meningkatkan kompetensi siswa tersebut sehingga dapat mengikuti KSN-P dengan maksimal.

\section{METODE}

Pelaksanaan kegiatan pendampingan seorang siswa calon peserta KSN-P yang berasal dari SMA Negeri 2 Waingapu dilaksanakan tanggal 6 hingga 13 September 2021 bertempat di Ruang Kuliah Universitas Kristen Wira Wacana Sumba. Kegiatan ini merupakan salah satu bentuk implementasi keilmuan Fisika serta Matematika oleh para dosen di Prodi Pendidikan Matematika kepada masyarakat, dalam hal ini siswa SMA Negeri 2 Waingapu sebagai salah satu sekolah mitra Kerjasama. Pelaksanaan kegiatan pendampingan dilakukan secara rutin dalam kurun waktu kurang lebih 1 minggu dengan durasi 2 jam pada setiap pertemuan. Adapun jadwal pelaksanaan pendampingan dapat dilihat pada Tabel 1. 
Berdasarkan Tabel 1 terlihat bahwa kegiatan awal yang dilakukan adalah pemberian soal tes pendahuluan kepada siswa dampingan. Hal ini bertujuan untuk mengetahui pengetahuan awal yang telah dikuasainya terkait materi KSN-P. Berdasarkan informasi tersebut diketahui bahwa siswa dampingan belum menguasai secara mendalam beberapa konsep Fisika yang menjadi dasar dalam pengerjaan soal KSN-P. Konsep-konsep yang belum dikuasai siswa adalah terkait kinematika, dinamika, energi, dan tumbukan. Pada dasarnya, konsep tersebut telah dipelajari oleh siswa, akan tetapi belum dapat diimplementasikan pada saat mengerjakan soal dengan variasi yang berbeda. Demikian halnya dengan konsep matematika, sebagai yang tidak kalah penting untuk dikuasai siswa dalam menyelesaikan soal. Dari hasil observasi masih ditemukan bahwa siswa belum menguasai konsep aljabar, diferensial, dan lain-lain.

Tabel 1. Jadwal pelaksanaan pendampingan

\begin{tabular}{lll}
\hline No & Hari/Tanggal & \multicolumn{1}{c}{ Materi Pendampingan } \\
\hline 1 & 6 September 2021 & Tes pengetahuan dasar terkait konsep Fisika dan Matematika dasar \\
2 & 7 September 2021 & Kinematika gerak satu dimensi, dan penguatan konsep matematika \\
3 & 8 September 2021 & Kinematika gerak dua dimensi, dan penguatan konsep matematika \\
4 & 9 September 2021 & Dinamika gerak, dan penguatan konsep matematika \\
5 & 10 September 2021 & Dinamika rotasi, dan penguatan konsep matematika \\
6 & 11 September 2021 & $\begin{array}{l}\text { Energi, tumbukan dan momentum, dan penguatan konsep } \\
\text { matematika }\end{array}$ \\
7 & 12 September 2021 & Tes akhir \\
\hline
\end{tabular}

Selanjutnya, dari hasil pretest tersebut, pelaksana kegiatan Pengabdian kepada Masyarakat, dalam hal ini dosen Prodi Pendidikan Matematika Universitas Kristen Wira Wacana Sumba merencanakan bentuk pendampingan yang akan diselenggarakan. Bentuk pembelajaran yang digunakan adalah ceramah interaktif serta latihan soal dengan waktu penyelesaian yang dibatasi. Pemilihan ceramah interaktif sebagai salah satu bentuk metode pendampingan merujuk pada hasil penelitian terdahulu bahwa metode ceramah interaktif dapat memudahkan siswa dalam memahami materi yang diajarkan oleh guru (Savira \& Fatmawati, 2018). Selain itu, penggunaan ceramah interaktif ini dapat meningkatkan minat siswa untuk belajar (Rikawati \& Sitinjak, 2020). Metode ini digunakan oleh tim pelaksana pengabdian kepada masyarakat dalam menyampaikan materi-materi terkait konsep yang belum dapat dikuasai oleh siswa.

Pada kegiatan pendampingan ini tim pelaksana tidak hanya menggunakan satu bentuk metode saja, melainkan dikombinasikan juga dengan metode lain. Pada kegiatan-kegiatan pendampingan di tahun sebelumnya, tim pelaksana pengabdian kepada masyarakat menggunakan metode diskusi kelompok. Akan tetapi hal tersebut tidak dapat dilakukan pada kegian pendampingan ini. Hal ini karena calon peserta KSN-P yang didampingi berjumlah 1 (satu) orang, sehingga tidak memungkinkan untuk dilakukannya diskusi kelompok. Oleh karena itu, metode lain yang dipilih adalah pemberian latihan soal. Latihan soal ini dikerjakan oleh siswa dampingan dengan durasi waktu yang dibatasi. Dengan demikian, siswa tersebut akan terlatih dan terbiasa untuk mengerjakan soal dengan durasi waktu pengerjaan soal seperti pada kegiatan KSN-P sesungguhnya. Selain itu, hasil penelitian menunjukkan bahwa dengan pembatasan waktu dalam penyelesaian latihan soal dapat meningkatkan hasil belajar peserta didik (Puryati, 2017). Kegiatan pedampingan ini dilaksanakan dengan mematuhi protokol kesehatan yang ditetapkan oleh pemerintah. Dengan demikian, dapat mencegah terjadinya penyebaran pandemic COVID-19 selama kegiatan berlangsung.

\section{HASIL DAN PEMBAHASAN}

Berdasarkan hasil pre test yang diberikan kepada siswa tersebut, diketahui bahwa siswa tersebut belum menguasai konsep-konsep Fisika secara mendalam. Siswa calon peserta KSN-P cenderung menghafal rumus-rumus Fisika, akan tetapi belum dapat mengaitkan antara persamaan yang satu dengan persamaan yang lain karena tidak memahami konsep dengan baik. 
Mata pelajaran Fisika pada dasarnya merupakan matapelajaran yang kurang disukai oleh peserta didik, oleh karena itu banyak siswa yang berfokus menghafalkan persamaan-persamaan Fisika, namun tidak mengerti konsep Fisika (Sari et al., 2012). Siswa tersebut pun belum menguasai konsep-konsep Matematika yang terkait dengan penyelesaian soal Fisika. Padahal, menurut hasil penelitian diketahui bahwa pengetahuan terkait materi Matematika turut mempengaruhi keterampilan siswa dalam menyelesaikan soal Fisika (Wiladatika et al., 2017).

Dosen Prodi Pendidikan Matematika selanjutnya memberikan penguatan konsep-konsep Fisika yang belum dikuasai oleh siswa beserta kiat-kiat khusus yang diperlukan untuk dapat menyelesaikan soal dengan tepat. Adapun konsep-konsep Fisika yang ditekankan dalam pendampingan ini adalah kinematika, dinamika, gerak rotasi, hukum-hukum Newton terkait gerak, dan materi-materi lain yang telah ditunjukkan pada Tabel 1. Penyajian konsep-konsep tersebut dilakukan melalui ceramah interaktif. Selain itu, siswa diberikan penguatan terkait persamaan-persamaan Matematika yang berhubungan dengan penyelesaian soal KSN-P. Penguatan konsep Matematika dilakukan dalam setiap pertemuan, terutama ketika ditemukan bahwa siswa melakukan kesalahan perhitungan dikarenakan tidak memahami cara memecahkan masalah dengan menggunakan Matematika.

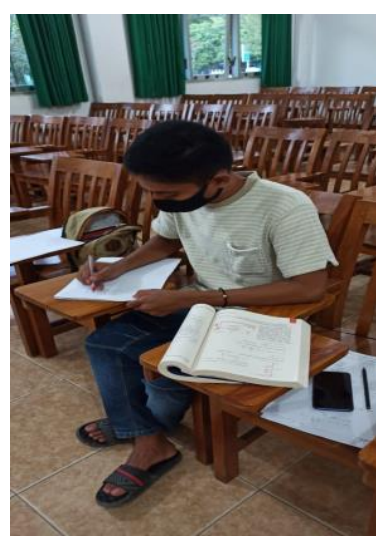

Gambar 1. Siswa dampingan sedang mengerjakan latihan soal

Selanjutnya, dosen pelaksana PkM juga memberikan latihan-latihan soal di setiap pertemuan pendampingan kepada calon peserta KSN-P untuk dikerjakan dengan durasi waktu yang dibatasi. Hal ini bertujuan untuk membiasakan siswa tersebut terkait durasi pengerjaan soal pada saat mengikuti KSN-P. Adapun tingkat kerumitan soal latihan yang diberikan disesuaikan dengan soal-soal KSN-P di tahun-tahun sebelumnya. Kemudian, siswa mempresentasikan hasil kerjanya kepada tim pelaksana PkM dan selanjutnya dikoreksi, sehingga dapat diketahui bagian-bagian yang belum dimengerti. Pada bagian ini diselingi dengan kegiatan tanya jawab oleh tim pelaksana PkM dengan siswa tersebut untuk memperoleh umpan balik dari siswa calon peserta KSN-P.

Pada kegiatan pendampingan ini ditemukan bahwa terdapat beberapa faktor yang menjadi kendala bagi siswa pada saat menyelesaikan soal latihan. Faktor pertama adalah siswa mengerjakan soal secara terburu-buru, hal ini menyebabkan siswa tersebut tidak begitu teliti dalam menuliskan persamaan ataupun dalam melakukan perhitungan. Faktor kedua adalah siswa tidak percaya diri pada saat mengerjakan latihan soal. Meskipun demikian, siswa tersebut tetap melaksanakan pengerjaan soal Latihan soal secara mandiri di rumah, untuk mereview materi yang dibahas pada saat pendamping. Kemandirian serta rasa percaya diri tersebut tentu saja turut mempengaruhi kemampuan siswa tersebut dalam menyelesaikan soal latihan yang diberikan. Hal ini sejalan dengan penelitian terdahulu yang menyatakan bahwa self efficacy dan kemandirian belajar memiliki keterkaitan dengan kemampuan siswa dalam memecahkan masalah matematis (Amalia et al., n.d.). Oleh karena itu, tim pelaksana juga memberikan motivasi kepada siswa tersebut, sehingga siswa dampingan dapat membangkitkan rasa percaya dirinya, dan giat mengerjakan latihan soal secara mandiri. 


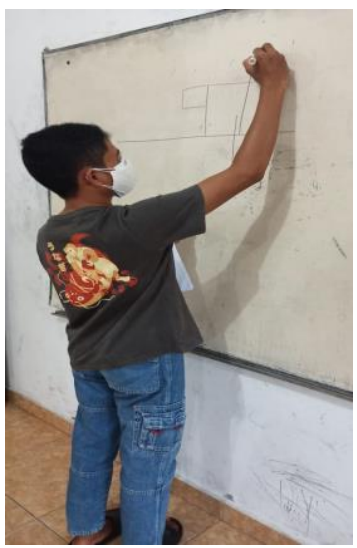

Gambar 2. Siswa sedang mempresentasikan hasil pekerjaannya

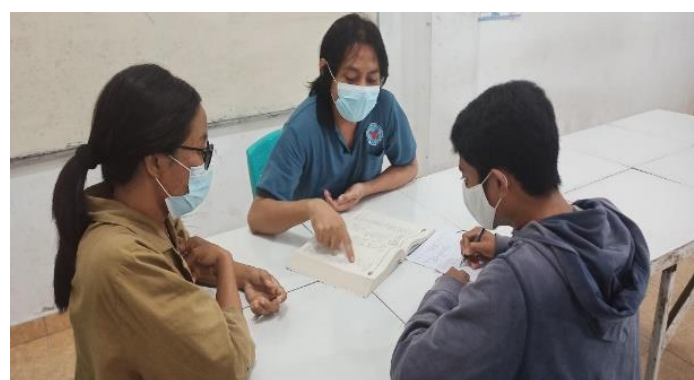

Gambar 3. Proses pendampingan oleh tim pelaksana PkM

Hasil pendampingan yang diberikan kepada siswa tersebut memberikan dampak positif bagi siswa tersebut. Di mana siswa tersebut menunjukkan peningkatan kemampuan setelah diberikan pendampingan. Pada beberapa pertemuan pendampingan, siswa masih berfokus pada satu konsep materi Fisika saja pada saat mengerjakan sebuah latihan soal. Akan tetapi, setelah diberikan pendampingan secara intensif, siswa menunjukkan peningkatan, yakni siswa tersebut telah dapat menghubungkan beberapa konsep dalam Fisika untuk menyelesaikan soal-soal latihan yang diberikan.

Peningkatan juga ditunjukkan dalam hal keterampilan untuk menggunakan konsepkonsep Matematika yang diperlukan ketika menyelesaikan soal. Hal ini turut didukung oleh kepercayaan diri siswa yang kian meningkat, sehingga, siswa calon peserta KSN-P tersebut memiliki kesiapan yang lebih baik dalam mengikuti KSN-P. Karena siswa tersebut telah mengalami peningkatan pengetahuan terkait konsep-konsep Fisika, maupun keterampilan menggunakan konsep Matematika dalam menyelesai soal, dengan demikian kegiatan PkM yang dilakukan oleh dosen Prodi Pendidikan Matematika telah mencapai tujuan yang direncanakan.

\section{KESIMPULAN}

Berdasarkan kegiatan PkM yang telah dilaksanakan dapat disimpulkan bahwa kegiatan pendampingan telah dilaksanakan dengan baik dan telah mencapai tujuan pelaksanaan kegiatan yang diharapkan. Bentuk pencapaian yang telah diperoleh melalui kegiatan PkM ini adalah terjadinya peningkatan kemampuan siswa terkait konsep-konsep dasar Fisika yang akan digunakan dalam menyelesaikan soal-soal KSN-P, serta peningkatan keterampilan dalam menggunakan persamaan-persamaan Matematika dalam menyelesaikan soal-soal.

\section{UCAPAN TERIMA KASIH}

Penulis berterima kasih kepada Lembaga Penelitian dan Pengabdian kepada Masyarakat (LPPM) Unkriswina Sumba yang telah mendanai pelaksanaan kegiatan pengabdian kepada masyarat ini. 


\section{DAFTAR PUSTAKA}

Amalia, A., Syafitri, L. F., Sari, V. T. A., \& Eti, H. E. (n.d.). Hubungan Antara Kemampuan Pemecahan Masalah Matematik dengan Self Efficacy dan Kemandirian Belajar Siswa SMP. 8.

Bhagaskara, A. E., Afifah, E. N., \& Putra, E. M. (2021). Pembelajaran Dalam Jaringan [Daring] Berbasis WhatsApp Di SD Yapita. Zahra: Research And Tought Elementary School Of Islam Journal, 2 Nomor 1, 13-23.

Hairiah. (2021). Model Pembelajaran Pada Masa COVID-19 Di Indonesia. Journal Of Instructional and Development Researches, 1 Nomor 1, 1-9.

Ibrahim, I. U., Kusri Mumpuni, \& Tim Juri KSN. (2021). Panduan Pelaksanaan Kompetisi Sain Nasional Tingkat Provinsi [KSN-P] Tahun 2021. Pusat Prestasi Nasional.

Puryati, E. (2017). Meningkatkan Hasil Belajar Siswa Dengan Menyelesaikan Soal Latihan Matematika Melalui Pembatasan Waktu Pada Setiap Pertemuan. Jurnal Prisma Universitas Suryakancana, 6 Nomor 2, 192-201.

Rikawati, K., \& Sitinjak, D. (2020). Peningkatan Keaktifan Belajar Siswa dengan Penggunaan Metode Ceramah Interaktif. 2(2), 40-48. https://doi.org/10.21580/jec.2020.2.2.6059

Sari, A. T., Bektiarso, S., \& Yushardi. (2012). Penerapan Model Pembelajaran Generatif Dengan Metode Demonstrasi Dalam Pembelajaran Fisika Di SMP. Jurnal Pembelajaran Fisika, 1 Nomor 2, 145-151.

Savira, A. N., \& Fatmawati, R. (2018). Peningkatan Minat Belajar Siswa dengan Menggunakan Metode Ceramah Interaktif. 1, 14.

Standar Nasional Pendidikan Tinggi Nomor 3, S. N. P. T. (2020). Peraturan Menteri Pendidikan Dan Kebudayaan Republik Indonesia Nomor 3 Tahun 2020 (pp. 1-75).

Talu, M. M., Santhalia, P. W., \& Kristiyanto, W. H. (2021). Efektivitas Pembelajaran Fisika Daring di Era Pandemi COVID-19 Pada Sekolah Yang Kesulitan Akses Internet [Studi Kasus Sekolah di Kabupaten Sumba Barat]. Jurnal Penelitian Pembelajaran Fisika, 12 Nomor 2, 196-202. https://doi.org/10.26877/jp2f.v12i2.9369

Wiladatika, L., Sitompul, S. S., \& Mahmuda, D. (2017). Hubungan Keterampilan Matematika Dengan Kemampuan Menyelesaikan Soal Materi Gaya Pada Siswa SMP Mujahidin Pontianak. Jurnal Pendidikan Dan Pembelajaran: Khatulistiwa, 6 Nomor 1, 1-9. 